\title{
Gambaran Motivasi Kerja dan Work Engagement Ditinjau dari Urutan Kelahiran Karyawan
}

\author{
MUTIARA MIRAH YUNITA \\ Fakultas Psikologi, Universitas Bunda Mulia \\ Email: mutiara.mirah@gmail.com
}

\begin{abstract}
Abstrak: Perusahaan seringkali mengalami permasalahan akibat motivasi kerja karyawan yang rendah. Ada berbagai faktor yang dapat mempengaruhi hal tersebut salah satunya dari kepribadian individu itu sendiri yang juga dibentuk dari urutan kelahiran. Hasil penelitian menunjukkan pada variabel motivasi kerja, anak tunggal dan anak pertama memiliki nilai tertinggi. Kemudian pada variabel work engagement, anak tunggal dan anak pertama memiliki nilai tertinggi. Sedangkan pada dimensi vigor, anak tunggal dan anak tengah memiliki nilai tertinggi. Kemudian pada dimensi dedication, anak pertama dan anak terakhir memiliki nilai tertinggi. Pada dimensi absorption, anak pertama dan anak terakhir memiliki nilai tertinggi. Implikasi dalam penelitian ini adalah perusahaan dapat mempertimbangkan mengenai urutan kelahiran sebagai sarana dalam menempatkan karyawan dalam suatu jabatan. Selain itu, hasil dari penelitian ini diharapkan seorang atasan dapat memprediksikan motivasi dan work engagement karyawan dalam bekerja. Selain itu, perusahaan dapat mengembangkan strategi pembelajaran dalam menghadapi motivasi dan work engagement yang rendah sesuai dengan urutan kelahiran.
\end{abstract}

Kata kunci: motivasi kerja, work engagement, urutan kelahiran

\begin{abstract}
Companies often have experiences problem due to low motivation in employee. There are various factors that can influence. One of them is the individual's personality which is also formed from the birth's order. The results of this research showed that the variable work motivation, single child and first child had the highest value. Then in the work engagement variable, the only child and the first child have the highest value. Whereas in the dimension of vigor, single children and middle children have the highest value. Then in the dimension of dedication, the first child and the last child have the highest value. In absorption, the first child and the last child have the highest value. The implication in this study is that companies can consider the birth order as a means of placing employees in a position. In addition, the results of this study are expected to lead a supervisor to predict employee motivation and work engagement in work. In addition, companies can develop learning strategies in the face of low motivation and work engagement in accordance with the birth order
\end{abstract}

Keywords: work motivation, work engagement, birth order

\section{PENDAHULUAN}

Berdasarkan survei yang dilakukan oleh PMSM Indonesia (2016) diketahui bahwa 80\% pekerja di Indonesia dikategorikan sebagai not engaged di tempat kerja dan rinciannya hanya $13 \%$ pekerja yang fully engaged. Berdasarkan studi bertajuk "Employee Engagement Among Millennials" yang dilakukan oleh Dale
Carnegie Indonesia (dalam Anwar, 2017) disebutkan hanya $25 \%$ tenaga kerja milenial (kelahiran 1986-2000) yang terlibat sepenuhnya dengan perusahaan tempat mereka bekerja. Berdasarkan data BPS 2016 (dalam Rappler.com, 2017), dari total jumlah angkatan kerja di Indonesia yang mencapai lebih dari 160 juta orang, sebanyak $4 \%$ di antaranya adalah 
generasi milenial, tepatnya sekitar 62,5 juta orang sehingga generasi milenial ini dalam waktu singkat akan dapat menjadi angkatan kerja terbesar di Indonesia menggantikan generasi $\mathrm{X}$ yang akan mulai memasuki masa pensiun.

Kurangnya engagement dari karyawan dapat berdampak pula terhadap produktivitas karyawan dalam bekerja. Hal ini didukung berdasarkan penelitian yang dilakukan oleh Hanaysha (2016) yang menemukan bahwa produktivitas karyawan dapat ditingkatkan apabila adanya work engagement yang baik dari karyawan. Oleh karena itu beberapa perusahaan dapat mengalami masalah apabila karyawan yang bekerja tidak memiliki work engagement karena dapat mempengaruhi produktivitas karyawan. Selain work engagement terdapat faktor lain yang di dalamnya dapat mempengaruhi produktivitas karyawan, yaitu motivasi kerja. Hal ini juga didukung berdasarkan penelitian Forson (2012) yang menemukan bahwa motivasi kerja pada karyawan dapat berkontribusi terhadap produktivitas karyawan. Dengan demikian, baik work engagement dan motivasi kerja merupakan hal yang dapat membantu produktivitas pada karyawan, namun terdapat beberapa faktor yang dapat memicu motivasi kerja dan work engagement untuk tumbuh.

Salah satu faktor yang dapat memicu motivasi kerja dan work engagement adalah kepribadian dalam diri individu yang terbentuk sejak masa kanak-kanak hingga dewasa. Berdasarkan penelitian meta analysis (Wright, 2003) yang melibatkan penelitian dari tahun 1887-2000 ditemukan 65 penelitian dari 2000 penelitian yang memiliki korelasi signifikan antara kepribadian big five dengan motivasi karyawan dalam bekerja, dimana semakin tinggi conscientiousness dihubungkan dengan motivasi kerja yang lebih tinggi dan semakin tinggi neuroticism dihubungkan dengan motivasi kerja yang lebih rendah. Sementara berdasarkan penelitian Mróz dan Kaleta (2016), kepribadian big five khususnya extraversion dan conscientiousness memiliki hubungan positif signifikan dengan work engagement, sehingga semakin tinggi kecenderungan kedua kepribadian tersebut akan berkontribusi terhadap semakin tingginya work engagement.

Salah satu aspek yang dapat membentuk suatu pola kepribadian ini adalah urutan kelahiran individu. Berdasarkan penelitian yang dilakukan oleh Paulhus, Trapnell, dan Chen (1999) diketahui bahwa urutan kelahiran dapat membentuk kepribadian dan tingkat pencapaian prestasi individu dengan hasil penelitian menunjukkan bahwa anak yang dilahirkan pertama memiliki kecenderungan conscientiousness pencapaian prestasi paling tinggi dibandingkan dengan anak dari urutan kelahiran yang lain. Hasil penelitian lain yang mendukung urutan kelahiran berkontribusi terhadap kepribadian adalah penelitian Al-Khayat (2016) yang menemukan bahwa terdapat hubungan signifikan antara urutan kelahiran dengan kepribadian anak serta pencapaian prestasi dimana anak tertua dan tunggal ditemukan memiliki pencapaian prestasi tertingi dibanding anak tengah dan anak terakhir. Dengan hasil penelitian yang sudah ada maka sebenarnya urutan kelahiran memegang peranan penting dalam menentukan pencapaian prestasi.

Menurut Adler (dalam Feist \& Feist, 2010) menyatakan bahwa anak-anak sesuai dengan urutan kelahirannya memegang posisi 
kekuasaan yang berbeda. Adler meyakini bahwa keturunan, lingkungan dan kreativitas individual bergabung membentuk kepribadian seseorang. Kondisi ini akan membentuk pola kepribadian individu dan mempengaruhi motivasi seseorang untuk mencapai sesuatu ketika dewasa. Salah satunya adalah motivasi kerja yang tercermin dalam work engagement. Tanpa adanya motivasi kerja maka individu tidak akan memperlihatkan work engagement yang tinggi dalam bekerja sehingga pada akhirnya karyawan dapat dinilai bahwa dirinya memiliki produktifitas kerja yang tinggi. Akan tetapi jika ditinjau dari urutan kelahirannya, seseorang dapat saja memiliki perbedaan dalam motivasi kerja dan work engagement. Meskipun urutan kelahiran bukan merupakan satu-satunya pemicu motivasi dalam bekerja dan work engagement. Urutan kelahiran dapat saja menjadi faktor yang dapat mempengaruhi pola kebiasaan pada perilaku individu yang terbentuk atau terpola dari sejak masa kanakkanak hingga dewasa sesuai dengan posisi kekuasaan yang didapatkan masing-masing anak sesuai dengan urutan kelahirannya. Oleh sebab itu, peneliti ingin mengetahui bagaimana gambaran motivasi kerja dan work engagement ditinjau dari urutan kelahiran karyawan, serta hubungan antara motivasi kerja dengan work engagement karyawan.

Motivasi Kerja. Motivasi kerja didefinisikan oleh Pinder (dalam Kanfer, 2012) sebagai suatu kumpulan dorongan energi yang berasal baik dari dalam diri maupun luar diri individu untuk memulai suatu perilaku yang berhubungan dengan pekerjaan, dan menentukan bentuk, arah, intensitas serta durasi dari perilaku yang dilakukan.
Menurut Salanova dan Kirmanen (2010), motivasi dapat dibedakan menjadi motivasi intrinsik dan ekstrinsik. Motivasi intrinsik dapat dijelaskan sebagai proses motivasi dari melakukan pekerjaan tersebut sendiri hingga dapat memuaskan kebutuhan pribadi karyawan. Motivasi intrinsik merupakan sesuatu yang dibentuk oleh diri sendiri dan seseorang mencari pekerjaan yang dapat memuaskan kebutuhan tersebut. Sementara pada motivasi ekstrinsik dijelaskan sebagai sejumlah usaha yang diberikan seseorang untuk memotivasi diri mereka. Contoh motivasi eksrinsik dapat berupa penghargaan dari perusahaan seperti kenaikan gaji, pangkat atau promosi.

Grant dan Shin (2012) menjelaskan motivasi kerja dapat dijelaskan dengan menggunakan 5 sudut pandang teori yang terdiri atas: (1) expectancy theory, (2) equity theory, (3) goal setting theory, (4) job design, (5) self-determination theory. Expectancy theory menjelaskan bahwa motivasi kerja karyawan didasarkan pada kesesuaian antara usaha yang harus dikeluarkan karyawan dengan kemungkinan yang dimiliki oleh karyawan untuk mendapatkan hasil yang diinginkan. Tanpa adanya ekspektasi, maka karyawan merasa usahanya akan sia-sia. Equity theory menjelaskan bahwa karyawan akan termotivasi kerja jika input yang dilakukan karyawan (usaha, pengetahuan, kesetiaan) memiliki kesesuaian dengan hasil akhir yang didapatkan (gaji, bonus, keuntungan). Ketika karyawan merasa kurang dihargai maka karyawan dapat cenderung kurang produktif.

Goal setting theory menjelaskan motivasi karyawan ditentukan oleh tujuan yang sudah ditetapkan oleh karyawan dalam bekerja 
sehingga karyawan akan termotivasi hanya jika sudah memiliki tujuan terlebih dahulu. Tujuan yang spesifik dan sulit dicapai dapat memicu tingginya kinerja karyawan untuk mencoba mencapai tujuan tersebut. Job-design menjelaskan motivasi kerja karyawan dapat juga bergantung dari bagaimana struktur pekerjaan karyawan dibentuk. Desain pekerjaan yang dianggap dapat memotivasi kerja karyawan harus melibatkan unsur pengalaman bermakna, tanggung jawab atas hasil akhir, dan pengetahuan akan hasil akhir. Self-determination theory menjelaskan motivasi karyawan didasarkan pada tiga kebutuhan psikologis dasar yang terdiri dari otonomi, kompetensi, dan keterhubungan. Otonomi mengacu pada perasaan akan pilihan dan keputusan mandiri, kompetensi mengacu pada perasaan mampu akan kemampuan diri sendiri, keterhubungan mengacu pada perasaan terhubung dan kebersamaan dengan orang lain.

Work Engagement. Schaufeli dan Bakker (2010) membedakan definisi antara work engagement dan employee engagement, dimana work engagement didefinisikan sebagai hubungan antara karyawan dengan pekerjaannya, sedangkan employee engagement didefinisikan sebagai bukan saja hubungan karyawan dengan pekerjaannya tetapi dapat mencakup hubungan karyawan dengan organisasinya juga. Menurut Shcaufeli (2012), work engagement merupakan sesuatu yang berlawanan dengan burnout dimana ketika seseorang mengalami burnout maka orang tersebut akan melihat suatu pekerjaan sebagai sesuatu yang menekan dan menyulitkan; sementara karyawan yang merasakan work engagement akan memiliki rasa semangat dan hubungan yang efektif dalam pekerjaannya. Schaufeli, Salanova, Gonzalez-Romá dan Bakker (2002), menjelaskan bahwa dimensi dalam work engagement terdiri atas (a) vigor, (b) dedication, dan (c) absorption. Vigor ditandai dengan tingkat energi yang tinggi dan resiliensi mental ketika bekerja dalam menghadapi kesulitan. Dedication ditandai dengan perasaan penting, antusiasme, inspirasi, rasa bangga dalam pekerjaannya. Absorption ditandai dengan sepenuhnya berkonsentrasi secara mendalam pada satu pekerjaan, dimana waktu berjalan dengan cepat dan memiliki kesulitan untuk melepaskan diri dari pekerjaan yang sedang dikerjakan.

\section{METODE}

Metode penelitian yang digunakan adalah metode penelitian kuantitatif dengan menggunakan kuesioner untuk mendapatkan data penelitian. Teknik sampling yang digunakan adalah purposive sampling dengan target partisipan karyawan yang tidak dibatasi oleh umur dan jenis kelamin. Teknik analisis yang digunakan adalah analisis deskriptif statistik dengan menggunakan program SPSS untuk mencari nilai rata-rata (mean) dari variabel yang ingin diukur. Peneliti menggunakan skala motivasi kerja dan work engagement scale yang diadaptasi dari Utretch Work Engagement Scale (UWES), dan pertanyaan tentang urutan kelahiran. Kategori urutan kelahiran dalam penelitian ini dibagi menjadi 5 kategori: (a) anak pertama, (b) anak tengah, (c) anak terakhir, (d) anak kembar, dan 
(e) anak tunggal. Proses penyebaran kuesioner dilakukan melalui google doc.

Instrumen Penelitian. Skala motivasi kerja disusun oleh peneliti menggunakan teori motivasi kerja dari Kanfer (2012) dalam bentuk skala likert 1-4 yang terdiri atas 2 dimensi yang mengukur motivasi internal (5 butir) dan motivasi eksternal (17 butir). Motivasi internal merupakan dorongan-dorongan untuk berprestasi yang sifatnya bersumber dari dalam diri seseorang dan hal ini meliputi pekerjaan seseorang, keberhasilan yang diraih, kesempatan untuk tumbuh, kemajuan dalam berkarier, dan pengakuan orang lain. Sementara motivasi eksternal merupakan faktor-faktor yang sifatnya ekstrinsik (pemeliharaan) bersumber dari luar diri seseorang. pemeliharaan mencakup status seseorang dalam organisasi, hubungan seorang karyawan dengan atasannya dan rekan-rekan kerjanya, kebijakan organisasi, sistem administrasi dalam organisasi, kondisi kerja dan sistem imbalan yang berlaku.

Skala work engagement diadaptasi dari Utretch Work Engagement Scale (UWES) yang merupakan alat ukur dalam bentuk skala likert 1-7 dan terdiri atas 3 dimensi yang mengukur vigor (6 butir), dedication (6 butir), Absorption ( 5 butir). Vigor ditandai dengan curahan energi dan mental yang kuat dalam bekerja, dan keberanian untuk berusaha sekuat tenaga dalam menyelesaikan suatu pekerjaan. Dedication ditandai dengan merasa terlibat sangat kuat dalam suatu pekerjaan dan mengalami rasa kebermaknaan, antuasiasme, kebanggaan, inspirasi dan tantangan. Absorption ditandai dengan dalam bekerja karyawan selalu penuh konsentrasi dan serius terhadap suatu pekerjaan sehingga dalam bekerja waktu terasa berlalu begitu cepat dan menemukan kesulitan dalam memisahkan diri dengan pekerjaan.

\section{HASIL}

Berdasarkan proses pengumpulan data didapatkan partisipan sebanyak 144 orang dengan rentang usia mulai dari 21 tahun hingga 43 tahun $($ mean $=28,06)$. Jumlah partisipan yang berjenis kelamin laki-laki terdiri atas 75 orang $(52,1 \%)$ dan berjenis kelamin perempuan terdiri atas 69 orang $(47,9 \%)$. Jumlah sebaran data karakteristik responden berdasarkan urutan kelahiran dapat dilihat pada tabel 1 .

Tabel 1. Hasil Data Deskriptif Partisipan Ditinjau Dari Urutan Kelahiran

\begin{tabular}{ccc}
\hline $\begin{array}{c}\text { Urutan } \\
\text { Kelahiran }\end{array}$ & $\mathbf{N}$ & $\begin{array}{c}\text { Persentase } \\
(\boldsymbol{\%})\end{array}$ \\
\hline Pertama & 30 & 20,8 \\
\hline Tengah & 30 & 20,8 \\
\hline Terakhir & 30 & 20,8 \\
\hline Kembar & 30 & 20,8 \\
\hline Tunggal & 24 & 16,7 \\
\hline Total & $\mathbf{1 4 4}$ & $\mathbf{1 0 0}$ \\
\hline
\end{tabular}

Reliabilitas Instrumen. Hasil reliabilitas alat ukur dengan menggunakan 144 partisipan ditemukan bahwa skala motivasi kerja memiliki cronbach alpha sebesar 0,440 untuk dimensi motivasi internal dan 0,823 untuk dimensi motivasi eksternal. Standar reliabilitas yang dapat diterima dalam penelitian ini menggunakan nilai alpha yang berkisar antara .65 sampai .70 (Cohen \& Swerdik, 2009). Dengan demikian hasil reliabilitas skala motivasi kerja dimensi motivasi internal tidak dapat digunakan karena tidak memenuhi standar reliabilitas. Oleh karena itu dalam 
penelitian ini skala motivasi kerja yang digunakan hanya dimensi eksternal saja.

Hasil reliabilitas alat ukur work engagement scale menggunakan 144 partisipan ditemukan memiliki cronbach alpha sebesar 0,823 untuk dimensi vigor; 0,849 untuk dimensi dedication; dan 0,803 untuk dimensi absorption. Berdasarkan standar reliabilitas maka hasil reliabilitas work engagement scale dalam penelitian ini memiliki reliabilitas yang baik dan dapat diterima untuk digunakan dalam penelitian.

Uji Normalitas Data. Berdasarkan uji normalitas data menggunakan teknik analisis One Sample Kolmogorov Smirnov diketahui bahwa skor motivasi kerja dimensi eksternal, dan skor work engagement tidak terdistribusi normal $(\mathrm{sig}=0,000<0,05)$. Sehingga untuk mengetahui perbandingan skor motivasi kerja dan work engagement berdasarkan kelompok urutan kelahiran digunakan teknik analisis Kruskal Wallis sebagai alternatif dari One Way Anova untuk uji nonparametrik bila data tidak terdistribusi normal.

Uji Kruskal Wallis. Berdasarkan uji kruskal wallis diketahui bahwa nilai motivasi kerja dimensi eksternal ditinjau dari urutan kelahiran memiliki perbedaan yang signifikan ( $\operatorname{sig}=0,00$ $<0,01$; Chi-Square $=46,542 ; \mathrm{df}=4$ ) sehingga dapat disimpulkan terdapat motivasi kerja yang berbeda di antara anak pertama, anak tengah, anak terakhir, anak kembar, dan anak tunggal. Dari urutan nilai ranks diketahui kelompok anak yang memiliki nilai mean rank motivasi kerja dimensi eksternal tertinggi adalah anak tunggal dan kelompok anak yang memiliki nilai mean rank paling rendah adalah anak kembar. Anak pertama diketahui memiliki mean rank tertingi kedua, sedangkan anak terakhir diketahui memiliki mean rank yang sedikit lebih tinggi dalam motivasi kerja dimensi eksternal dibanding anak tengah. Hasil Uji Kruskal Wallis motivasi kerja dimensi eksternal dapat dilihat pada tabel 2.

Tabel 2. Hasil Uji Kruskal Wallis Data Motivasi Kerja Dimensi Eksternal

\begin{tabular}{ccc}
\hline $\begin{array}{c}\text { Urutan } \\
\text { Kelahiran }\end{array}$ & N & Mean Rank \\
\hline Pertama & 30 & 81,30 \\
\hline Tengah & 30 & 75,65 \\
\hline Terakhir & 30 & 75,80 \\
\hline Kembar & 30 & 31,05 \\
\hline Tunggal & 24 & 105,25 \\
\hline Total & $\mathbf{1 4 4}$ & \\
\hline & &
\end{tabular}

Berdasarkan uji kruskal wallis diketahui bahwa nilai work engagement ditinjau dari urutan kelahiran memiliki perbedaan yang signifikan $(\operatorname{sig}=0,00<0,01 ;$ Chi-Square $=$ 49,972; df = 4) sehingga dapat disimpulkan terdapat tingkat work engagement yang berbeda di antara anak pertama, anak tengah, anak terakhir, anak kembar, dan anak tunggal.

Dari urutan nilai ranks diketahui kelompok anak yang memiliki nilai mean rank work engagement tertinggi adalah anak tunggal dan kelompok anak yang memiliki nilai mean rank paling rendah adalah anak kembar. Anak pertama diketahui memiliki mean rank tertinggi kedua dalam work engagement dan anak terakhir diketahui memiliki urutan yang lebih tinggi dibanding anak tengah. Hasil Uji Kruskal Wallis work engagement dapat dilihat pada tabel 3. 


\section{PEMBAHASAN}

Tabel 3. Hasil Uji Kruskal Wallis Data

Work Engagement

\begin{tabular}{ccc}
\hline $\begin{array}{c}\text { Urutan } \\
\text { Kelahiran }\end{array}$ & N & Mean Rank \\
\hline Pertama & 30 & 94,62 \\
\hline Tengah & 30 & 62,70 \\
\hline Terakhir & 30 & 64,20 \\
\hline Kembar & 30 & 38,88 \\
\hline Tunggal & 24 & 109,50 \\
\hline Total & $\mathbf{1 4 4}$ & \\
\hline
\end{tabular}

Analisis Tambahan. Berdasarkan analisis data deskriptif diketahui bahwa dimensi vigor dari work engagement dengan mean tertinggi dimiliki oleh anak tunggal $(M=5,20)$, urutan tertinggi kedua dimiliki oleh anak pertama ( $M$ $=5,03)$, urutan tertinggi ketiga dimiliki oleh anak terakhir $(M=4,76)$, urutan tertinggi keempat dimiliki oleh anak tengah $(M=4,52)$ dan urutan terendah diisi oleh anak kembar $(M$ $=3,98)$. Sementara itu bila melihat dimensi dedication dari work engagement maka mean tertinggi juga dimiliki oleh anak tunggal $(M=$ $5,80)$, urutan tertinggi kedua dimiliki oleh anak pertama $(M=5,16)$, urutan tertinggi ketiga dimiliki oleh anak terakhir $((M=5,05)$, urutan tertinggi keempat dimiliki oleh anak tengah ( $M$ $=5,04)$ dan urutan terendah diisi oleh anak kembar $(M=4,12)$. Pada dimensi absorption dari work engagement maka mean tertinggi juga dimiliki oleh anak tunggal $(M=5,63)$, tertinggi kedua dimiliki oleh anak pertama $(M$ $=5,20)$, tertinggi ketiga dimiliki oleh anak terakhir $(M=4,81)$, tertinggi keempat dimiliki oleh anak tengah $(M=4,56)$, dan urutan terendah diisi oleh anak kembar $(M=4,51)$.
Pada anak tunggal diketahui memiliki work engagement yang paling tinggi dan dalam dimensi vigor juga ditemukan anak tunggal memiliki nilai paling tinggi dibanding dengan anak pertama, tengah, terakhir dan kembar. Menurut Adler (dalam Feist and Feist, 2010) mengatakan bahwa pada anak tunggal memiliki sifat ambisius, cepat dan tepat, giat dan enerjik, berorientasi pada diri sendiri, selalu berusaha tampil mempesona, menjaga perilaku, dan mengontrol diri secara ketat yang selalu menjaga penampilannya kapan dan di mana pun, dan percaya pada pendapat diri sendiri. Hal ini didukung dengan motivasi kerja dimensi eksternal yang juga memiliki skor paling tinggi pada anak tunggal.

Sedangkan anak pertama memiliki nilai tertinggi kedua pada work-engagement, dan juga memiliki nilai tertinggi kedua dalam dimensi dedication dan absorption. Menurut Adler (dalam Feist and Feist, 2010) anak pertama memiliki ciri-ciri serius, sabar, tekun, memiliki konsentrasi yang kuat, percaya diri ketika merasa didukung, perfeksionis, percaya diri untuk bermimpi dan merencanakan, merasa dihormati karena apa yang individu lakukan. Oleh sebab itu, motivasi kerja dalam dimensi hygiene anak pertama juga memiliki skor yang paling tinggi kedua setelah anak tunggal.

Pada anak terakhir memiliki skor tertinggi ketiga setelah anak pertama pada dimensi dedication, absorption dan motivasi kerja eksternal. Hal ini dikarenakan anak terakhir sering dianggap sebagai bayi keluarga. Jadi anak terakhir biasanya mengikuti jejak-jejak dari anak pertama dan menengah. Anak terakhir memiliki sifat ramah tamah, penyayang, peduli, 
kreatif, empatik, dan percaya diri sehingga memiliki dedikasi dan absorption yang dapat dikatakan cukup dalam bekerja. Pada motivasi kerja dimensi eksternal dan 3 dimensi work engagement, anak tengah dan kembar memiliki skor lebih rendah dibanding dengan anak tunggal, pertama dan terakhir. Hasil ini menunjukkan bahwa urutan anak dalam keluarga sangat kompleks. Faktor seperti usia orangtua, urutan anak serta jenis kelamin saudara, agama, dan keyakinan budaya serta variabel penting lainnya juga berperan dalam membuat tahapan atas sesuatu yang dipelajari anak.

\section{KESIMPULAN}

Kesimpulan dalam penelitian ini adalah $\mathrm{H} 1$ diterima dengan hasil penelitian menunjukkan bahwa terdapat perbedaan yang signifikan pada motivasi kerja ditinjau dari urutan kelahiran. Selain itu dalam penelitian ini $\mathrm{H} 2$ juga diterima dengan hasil penelitian menunjukkan bahhwa terdapat perbedaan signifikan pada work engagement ditinjau dari urutan kelahiran karyawan. Implikasi dalam penelitian ini adalah perusahaan dapat mempertimbangkan mengenai urutan kelahiran sebagai sarana dalam menempatkan karyawan dalam suatu jabatan. Selain itu, hasil dari penelitian ini diharapkan seorang atasan dapat memprediksikan motivasi dan work engagement karyawan dalam bekerja. Selain itu, perusahaan dapat mengembangkan strategi pembelajaran dalam menghadapi motivasi dan work engagement yang rendah sesuai dengan urutan kelahiran.

\section{DAFTAR PUSTAKA}

Al-Khayat, M. (2016). The Effect of Birth Order on Personality Traits and Academic Performance at Sample of Families in Jordan. European Journal of Social Sciences, 52(2): 151-161.

Anwar, F. (2017). Engagement tenaga kerja milenial indonesia hanya $25 \%$. Diunduh dari https://youngster.id/featured/engagem ent-tenaga-kerja-milenial-indonesiahanya- 25

Cohen, R. J., \& Swerdik, M. E. (2009). Psychological testing and assessment: An introduction to tests and measurement (7th ed.). New York: McGraw-Hill

Feist \& Feist. (2010). Psychology of Personality, Ed 7. McGrawHill : New York.

Forson, J. E. M. (2012). Impact of motivation on the productivity of employees at GTbank Ghana (Unpublished Master Thesis) Kwame Nkrumah University Of Science And Technology. Diunduh dari

http://dspace.knust.edu.gh/bitstream/1 23456789/4297/1/JOYCE\%20ESSEL $\% 20 \mathrm{MC} \% 20 \mathrm{FORSON}$.pdf

Grant, A. M., \& Shin, J. (2012). Work motivation: Directing, energizing, and maintaining effort (and research). In Ryan, R. M. (Ed.), The oxford handbook of human motivation. New York: Oxford University Press

Hanaysha, J. (2016). Improving employee productivity through work engagement: Empirical evidence from 
higher education sector. Management Science Letters, 6 (2016): 61-70.

Kanfer, R. (2012). Work motivation: Theory, practice, and future directions. Dalam S.W. Kozlowski (Ed.), The oxford handbook of industrial and organizational psychology. Oxford, UK: Blackwell.

Mróz, J., Kaleta, K. (2016). Relationships between personality, emotional labor, work engagement and job satisfaction in service professions. International Journal of Occupational Medicine and Environmental Health, 29(5), 767782.https://doi.org/10.13075/ijomeh.1 896.00578

Paulhus, D., Trapnell, P. D., \& Chen, D. (1999). Birth Order Effects on Personality and Achievement Within Families. Psychological Science - PSYCHOL SCI. 10. 482-488. 10.1111/14679280.00193.

PMSM Indonesia (2016). Kita sedang dalam krisis engagement!! (kabar dari hr director breakfast -meeting). Diunduh dari https://www.pmsmindonesia.com/rubric/kita-sedangdalam-krisis-engagement-kabar-darihr-director-breakfast-meeting/

Rappler.com (2017). Infografis: milenial ogah terlibat sepenuhnya di perusahaan? Diunduh dari https://www.rappler.com/indonesia/ga ya-hidup/187169-infografis-millenialogah-terlibat-perusahaan

Salanova, A., \& Kirmanen, S. (2010). Employee satisfaction and work motivation. (Unpublished Bachelor's Thesis). Mikkeli University of Applied
Sciences. Diunduh dari https://www.theseus.fi/bitstream/handl e/10024/10979/Salanova_Anna_Kirm anen_Sanni.pdf

Schaufeli, W. B. (2012). Work engagement: What do we know and where do we go? Romanian Journal of Applied Psychology, 14(1): 3-10.

Schaufeli, W. B., \& Bakker, A. B. (2010). Defining and measuring work engagement: Bringing clarity to the concept. Work engagement: A handbook of essential theory and research, 10-24.

Schaufeli, W. B., Salanova, M., GonzalezRomá, V., \& Bakker, A. B. (2002). The measurement of engagement and burnout: A confirmative analytic approach. Journal of Happiness Studies, 3, 71-92

Wright, T. (2003). What Every Manager Should Know: Does Personality Help Drive Employee Motivation? The Academy of Management Executive (1993-2005), $\quad$ 17(2), 131-133. Retrieved from http://www.jstor.org/stable/4165963 